\title{
Strategi Pengembangan Wakaf Tunai Di Desa Sungai Pinang Kecamatan Rambutan Kabupaten Banyuasin
}

\author{
Romadona Adawiyah ${ }^{1}$, Dian Pertiwi \\ Fakultas Ekonomi dan Bisnis Islam \\ Universitas Islam Negeri Raden Fatah Palembang \\ E-mail: romadona.adawiyah@gmail.com,pertiwi.dian_uin@radenfatah.ac.id
}

\begin{abstract}
Abstrak
Wakaf memiliki peranan yang sangat penting dalam membantu perekonomian masyarakat di Indonesia, terutama wakaf yang dihimpun dalam wakaf tunai karena wakaf tunai merupakan wakaf yang siapapun dapat mewakafkan hartanya baik berupa uang maupun surat berharga untuk kemudian dikelola. Wakaf merupakan amal jariyah yang pahalanya tidak pernah terputus walaupun yang memberi wakaf telah meninggal dunia. Oleh karena itu, strategi pengembangan wakaf tunai di desa Sungai Pinang Kecamatan Rambutan Kabupaten Banyuasin harus dikelola dan dikembangkan dengan baik dan profesional sehingga mampu menopang potensi wakaf tunai untuk kemajuan dan eksistensi wakaf itu sendiri. Tujuan utama diinvestasikannya dana wakaf adalah untuk mengoptimalkan fungsi harta wakaf sebagai prasarana untuk meningkatkan kualitas hidup dan kehidupan sumber daya insani.
\end{abstract}

Kata kunci: Strategi Pengembangan, Wakaf Tunai

\section{A. Pendahuluan}

Wakaf telah di Syari'atkan dan telah dipraktikkan oleh umat Islam seluruh dunia sejak zaman Nabi Muhammad SAW sampai sekarang, termasuk oleh masyarakat Islam di Negara Indonesia. Wakaf memainkan peran ekonomi dan sosial yang sangat penting dalam sejarah Islam, wakaf berfungsi sebagai sumber pembiayaan bagi masjid-masjid, sekolah-sekolah, pengkajian dan penelitian, rumah-rumah sakit, pelayanan sosial dan pertahanan. Sebagai 
salah satu pilar kesejahteraan umat, wakaf mempunyai peran dan fungsi yang signifikan sebagai instrumen pengembangan ekonomi Islam dan sangat berperan dalam upaya mewujudkan perekonomian nasional yang sehat.

Wakaf pada saat ini sudah dikembangkan dengan berbagai metode untuk menghasilkan wakaf yang sangat bermanfaat bagi masyarakat salah satunya seperti wakaf tunai.

Dalam jangkauan yang lebih luas, kehadiran wakaf dapat pula dirasakan manfaatnya untuk meningkatkan taraf hidup masyarakat di bidang ekonomi, terutama sekali jika wakaf tunai dapat dikelola dengan manajemen yang rapi, teratur dan profesional. Namun, fungsi wakaf sebagai pemberdaya ekonomi masyarakat masih belum optimal. Hal ini mengingat mayoritas harta wakaf selama ini hanya dimanfaatkan untuk pembangunan keagamaan, yaitu masjid dan mushalla. Sedangkan pemanfaatan harta wakaf untuk sarana sosial dan kesejahteraan umat masih kurang mendapat perhatian.

Dalam mewakafkan harta, sebaiknya harus dilakukan sesuai dengan prinsip Islam dan peraturan perundang-undangan yang termasuk didalamnya menyerahkan harta tersebut dengan adanya ikrar dan diserahkan kepada nadzhir untuk dikelola. Karena peran nadzhir pun sangat penting untuk pengembangan/pemeliharaan harta wakaf. Pengelolaan harta wakaf tunai pun harus lebih diperhatikan oleh yang lebih berwenang dan lebih diprioritaskan. Kunci pengelolaan wakaf tunai terletak pada eksistensi pengelola wakaf, terutama nadzhir dan tim kerja yang solid untuk memaksimalkan peran wakaf khususnya wakaf tunai. Apabila wakaf dikelola secara profesional, maka ia akan menjadi lembaga Islam potensial yang berfungsi mendanai dan mengembangkan perekonomian umat.

\section{B. Wakaf}

Menurut Mazhab Syafi'i: Wakaf menurut Imam Nawawi, "Menahan harta yang dapat diambil manfaatnya tetapi bukan untuk dirinya, sementara benda itu tetap ada padanya dan digunakan manfaatnya untuk kebaikan dan mendekatkan diri kepada Allah". Menurut Mazhab Hanafi: Wakaf menurut Imam Syarkhasi, "Menahan harta dari jangkauan kepemilikan orang lain." Menurut Mazhab Maliki: Ibnu Arafah mendifinisikan wakaf 
dengan memberikan manfaat sesuatu, pada batas waktu keberadaannya, bersamaan tetapnya wakaf dalam kepemilikan si pemiliknya meski hanya perkiraan (Mardani, 2012 : 356). Menurut bahasa wakaf berasal dari waqf yang berarti radiah (terkembalikan), al-tahbiz (tertahan), al-tasbil (tertawan) dan al-man'u (mencegah). Wakaf adalah menahan sesuatu benda yang kekal zatnya, dan memungkinkan untuk diambil manfaatnya guna diberikan di jalan kebaikan (Suhendi, $2010: 239$ ).

Kata wakaf sendiri berasal dari kata kerja wakfa (fiil madi)-yaqilu (fil mudari')-waqfan (isim masdar) yang berarti berhenti atau berdiri (Alie, 1987 : 49). Adapun menurut istilah, wakaf berarti berhenti atau menahan harta yang dapat diambil manfaatnya tanpa musnah seketika dan untuk penggunaan yang mubah, serta dimaksudkan untuk mendapatkan keridaan Allah SWT (Basyir, 1987 : 5).

Imam Abu Hanifah (Imam Hanafi) memberikan pengertian wakaf adalah penahanan pokok sesuatu harta dalam tangan pemilikan wakaf dan penggunaan hasil barang itu, yang dapat disebutkan ariah atau commodate loan untuk tujuan-tujuan amal saleh. Sementara itu pengikut Abu Hanifah, Abu Yusuf dan Imam Muhammad memberikan pengertian wakaf sebagai penahanan pokok suatu benda dibawa hukum benda Tuhan yang Maha Kuasa, sehingga hak kepemilikan dari wakif berakhir dan berpindah kepada Tuhan yang Maha Kuasa untuk sesuatu tujuan, yang hasilnya dipergunakan untuk manfaat makhluk-Nya (Usman, 2009 : 52).

Menurut Mundzir Qahaf, wakaf adalah menahan harta baik secara abadi maupun sementara, untuk dimanfaatkan langsung atau tidak langsung dan diambil manfaat hasilnya secara berulang-ulang di jalan kebaikan untuk umum atau khusus (Qahaf, 2000 : 52). Sejalan dengan itu Maulana Muhammad Ali meruuskan wakaf sebagai penetapan yang bersifat abadi untuk memungut hasil dari barang yang diwakafkan guna kepentingan orang seorang, atau yang bersifat keagamaan atau untuk tujuan amal (Ali, 1976 : 467).

Dalam buku "Strategi Pengembangan Wakaf Tunai di Indonesia" yang diterbitkan oleh Direktorat Pemberdayaan Wakaf bahwa wakaf yang sangat populer di Indonesia masih terbatas pada persoalan tanah dan bangunan yang diperuntukkan untuk tempat ibadah dan pendidikan serta belakangan baru ada wakaf yang berbentuk tunai (cash) atau wakaf benda bergerak yang manfaatnya untuk kepentingan pendidikan, riset, rumah sakit, pemberdayaan ekonomi dan lain-lain. 
Wakaf uang sebenarnya sudah dikenal oleh para ulama klasis. Ulama yang membolehkan wakaf uang berpendapat, bahwa uang dapat diwakafkan asalkan uang tersebut diinvestasikan dalam usaha bagi hasil (mudharabah), kemudian keuntungannya disalurkan sesuai dengan tujuan wakaf. Dengan demikian uang yang diwakafkan tetap, sedangkan yang disampaikan kepada mauquf 'alaih adalah hasil pengembangan wakaf uang itu (Luthfi, 2013 : 115).

Di Indonesia praktif wakaf tunai baru mendapat dukungan dari Majelis Ulama Indonesia pada tahun 2002 dengan dikeluarkannya Fatwa Komisi Fatwa Majelis Ulama Indonesia tentang Wakaf Uang tanggal 28 Shafar 1423 Hijriah/11 Mei 2002 dalam menjawab surat Direktur Pengembangan Zakat dan Wkaf Departemen Agama Nomor Dt.1.III/5/BA.03.2/2772/2002 tanggal 26 April 2002 yang berisi tentang permohonan fatwa tentang wakaf uang (Usman, $2013: 106)$.

\section{Hukum Wakaf}

Sesungguhnya umar telah mendapatkan sebidang tanah di Khaibar.' Umar bertanya kepada Rasululullah saw.:

Apabilah perintahmu kepadaku berhubungan dengan tanah saya dapat ini? Jawab beliau:" jika engkau suka tahanlah tanah itu dan sedekahkanlah hasinya”, umar mengatakan bahwa "umar mengikuti nasehat Nabi itu, disediahkan tanahnya, dengan ketentuan tidak boleh dijual pokoknya, tidak boleh diwariskan dan dihibahkan; dan sedekah itu di peruntuhkan bagi fakir miskin, sanak keranat, untuk memerdekakan budak, untuk keperluan sabillilah, ibnusabil, dan tamu pengawas harta wakaf dibolehkan makan hasilnya sekedar yang diperlukan dan boleh juga memberi makan teman sejawatnya, tetapi jangan melampaui batas-batas yang pantas" (Ahma Azhar Basyir, 1960: 6).

Adapun ayat-ayat Alquran yang berhubungan dengan perintah melaksanakan wakaf, yang dijadikan dasar hukum wakaf yaitu sebagai berikut:

1. Surat Al-Baqarah ayat (267):

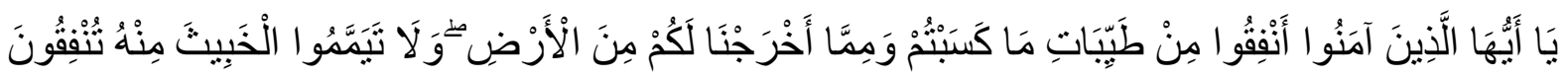

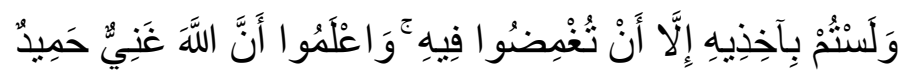


Hai orang-orang yang beriman, nafkahlah (di jalan allah) sebagai dari hasil usaha mu yang baik-baik dan sebagian dari hasil usahamu yang baik-baik dan dari sebagian dari apa yang kami keluarkan dari bumi untuk kamu.

2. Surat Al-'Imran ayat (92):

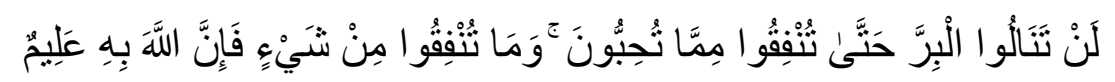

Kamu sekali-kali tidak samapai kepada baktin(yang sempurna) sebelum kamu menafkahkan sebagian harta yang kamu cintai.

3. Surah An-Nahl ayat (97):

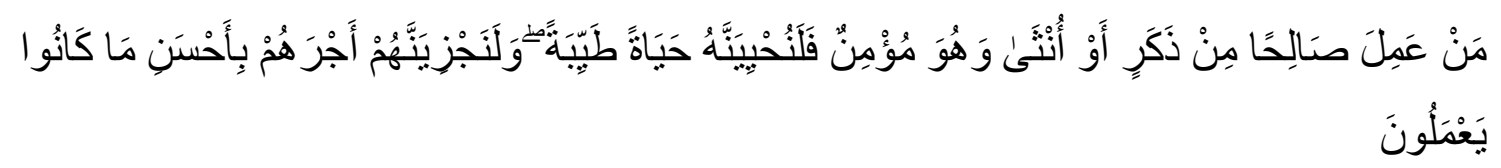

Barang siapa yang mengerjakan amal saleh, baik laki-laki maupun perempuan dalam keadaan beriman, maka sesunguhnya akan kami berikan kepadanya kehidupan yang baik.

4. Surah Al-Hajj Ayat (77):

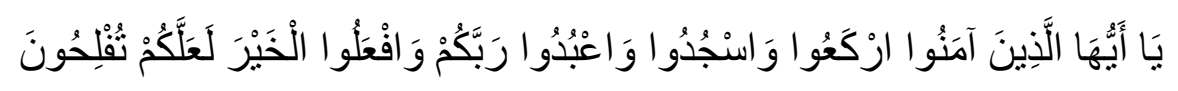

Hai orang-orang yang beriman, rukuklah kamu, sujudlah kamu sembahlah tuhanmu dan perbuatlah kebajikan supaya kamu memdapat kemenangan.

Kemudian hadis-hadis yang memberi isyarat kepada kita untuk melakasanakan ibadah wakaf tersebut, yaitu:

1. Hadis riwayat Dari Abu Hurairah radhiyallahu 'anhu, ia berkata bahwa Rasulullah shallallahu 'alaihi wa sallam bersabda, "Jika seseorang meninggal dunia, maka terputuslah amalannya kecuali tiga perkara (yaitu) : sedekah jariyah, ilmu yang dimanfaatkan, atau do'a anak yang sholeh" (HR. Muslim No.1631)

2. Diriwayatkan dari Ibn Umar ra ia berkata bahwa Umar mendapatkan bagian tanah di Khaibar, lalu ia pergi kepada Nabi SAW. Seraya berkata : Saya mendapat bagian tanah yang belum pernah saya dapatkan harta yang paling saya senangi daripadanya, maka 
apakah yang akan Nabi perintahkan pada saya ? Jawab Nabi : Bila engkau mau, tahanlah zat bendanya dan sedekahkan lah hasil daripadanya. Kemudian Umar menyedekahkan dan (menyuruh) supaya tidak dijual, tidak dihibahkan dan tidak diwariskan. Sedang manfaat benda itu diberikan kepada orang-orang fakir, sanak kerabat, hamba sahaya, sabilillah, tamu dan orang yang sedang berpergian atau musafir. Dan tidak dosa bagi orang yang mengurusi harta tersebut makan secara wajar atau memberi makan kepada temannya dengan tidak bermaksud memilikinya. (HR. Al-Bukhari dari Ibnu Umar).

\section{Wakaf Tunai}

Kata Waqf (jamaknya Awqaf) dapat diartikan sebagai sesuatu yang substansi (Wujud Aktiva) nya dipertahankan, sementara hasil manfaatnya digunakan sesuai dengan keinginan dari orang yang menyerahkan (Waqif), dengan demikian, wakaf berarti proses legal oleh seseorang yang melakukan amal nyata.

Wakaf merupakan amal islami yang berwujud aktiva tetap, seperti tanah dan bangunan. Namun dalam perkembangannya terdapat implementasi wakaf dengan "tunai” sebagaimana yang dilakukan pada masa kekhalifahan Utsmaniyah.

Wakaf dengan sistem "tunai" membuka peluang yang unik bagi penciptaan investasi bidang keagamaan, pendidikan, serta pelayanan sosial. Tabungan dari warga negara yang berpenghasilan tinggi dapat dimanfaatkan melalui penukaran sertifikat wakaf tunai, sedangkan pendapatan yang diperoleh dari pengelolaan waaf tunai tersebut dapat digunakan untuk berbagai kepentingan kemaslahatan umat.

Dari pengertian tersebut dapat dirumuskan bahwa wakaf tunai merupakan dana atau uang yang dihimpun oleh institusi pengelola wakaf (Nadzir) melalui penerbitan sertifikat wakaf tunai yang dibeli oleh masyarakat. Dalam pengertian lain wakaf tunai dapat juga diartikan mewakafkan harta berupa uang atau surat berharga yang dikelola oleh institusi perbankan atau lembaga keuangan syariah yang keuntungannya akan disedekahkan tetapi modalnya tidak bisa dikurangi untuk sedekahnya, sedangkan dana wakaf yang terkumpul selanjutnya dapat digulirkan dan diinvestasikan oleh nadzir ke dalam berbagai sektor usaha yang halal dan produktif, sehingga keuntungannya dapat dimanfaatkan untuk pembangunan umat dan bangsa secara keseluruhan (Haq, 2017 : 63). 


\section{E. Hukum Wakaf Tunai}

Terkait hukum wakaf tunai, tedapat perbedaan pendapat mengenai boleh atau tidaknya berwakaf tunai.

Imam al-Bukhari mengungkapkan bahwa Imam al-Zuhri memperbolehkan mewakafkan dinar dan dirham (keduanya merupakan mata uang yang berlaku pada saat itu), dengan cara menjadikan dinar dan dirham itu sebagai modal usaha (dagang), kemudian menyalurkan keuntungannya sebagai wakaf.

Wahbah Zuhaili juga mengungkapkan bahwa madzhab hanafi membolehkan wakaf tunai sebagai pengecualian, atas dasar Istihsan bi al-'Urfi, karena sudah banyak dilakukan masyarakat. Madzhab Hanafi memang berpendapat bahwa hukum yang ditetapkan berdasarkan 'Urf (adat kebiasaan) mempunyai kekuatan yang sama dengan hukum yang ditetapkan berdasarkan Nash. Cara melalukan wakaf tunai menurut madzhab Hanafi ialah dengan menjadikan modal usaha dengan sistem Mudharabah atau mubadha'ah, sedangkan keuntungannya disedekahkandipergunakan untuk kemaslahatan.

Sedangkan menurut Abn Abidin mengemukakan bahwa wakaf tunai yang dikatakan kebiasaan yang berlaku di masyarakat adalah kebiasaan yang berlaku di wilayah Romawi. Karena itu Ibn Abidin berpandangan bahwa wakaf tunai tidak boleh atau tidak sah, hal itu juga didasarkan pada pendapat ulama' syafi'iyah sebagaimana yang dikutip oleh al-Bakri, yang mengemukakan bahwa wakaf tunai tidak diperbolehkan karena dinar dan dirham (uang) akan lenyap ketika dibayarkan sehingga tidak ada lagi wujudnya.

\section{F. Sejarah Wakaf Tunai}

Wakaf pertama kali dilakukan oleh Rasulullah Muhammad Saw. ketika membangun masjid Quba di Madinah. Wakaf ini kemudian diikuti oleh Umar bin Khattab serta sahabatsahabat lain.

Bumi subur yang diwakafkan Umar bernama Tsamagh. Umar menyedekahkan hasilnya dan membuat ketentuan bahwa tanah itu tidak dijual, tidak dihibahkan, dan tidak pula diwariskan kepada kerabat maupun fakir miskin. Bagi pengelolanya tidak diharamkan untuk 
mengambil manfaat darinya, selama dalam batas yang ma'ruf, atau untuk menolong karibnya tanpa bermaksud mencari keuntungan. Pada masa Umar bin Al-Khatab menjadi Khalifah, beliau mencatat wakafnya dalam akta wakaf dengan dipersaksikan kepada para saksi dan mengumumkannya (Kasdi, 2017 : 36)

Bahkan seorang pejuang sejati, Khalid bin Walid, yang terkenal dengan kecerdasannya dan keberaniannya serta kecerdikannya dalam medan perang, juga tergugah untuk mewakafkan harta yang dimilikinya. Beliau mewakafkan alat-alat perangnya, seperti pedang, baju besi, kendaraan, kuda, dan lain-lain. Sungguh, mengangkat senjata di tengah medan perang itu besar pahalanya dan surga yang dijanjikan oleh Allah. Semua itu tentu saja dimengerti dan dipahami oleh Khalid bin Walid. Namun karena usianya sudah tidak lagi muda dan ia mengetahui bahwa wakaf memiliki pahala yang sifatnya mengalir tanpa putus, maka Khalid bin Walid pun tidak mau ketinggalan dalam amalan yang maha dahsyat ini(Muhith, $2013: 105$ )

Pada periode Abbasiyah, harta wakaf tidak dikelola di Baitul Mal, namun dikelola oleh Qadi, barulah kemudian dibentuk Baitul Mal khusus pengelolaan wakaf.

Pada masa dinasti Ayyubiyah di Mesir perkembangan wakaf tidak hanya sebatas pada benda tidak bergerak saja, akan tetapi juga benda bergerak seperti wakaf tunai.

Di Indonesia wakaf telah lama dikenal masyarakat, walaupun hanya dilakukan oleh sebagian kecil masyarakat, pemberian dana wakaf biasanya hanya dilakukan oleh orangorang yang mempunyai harta kekayaan yang cukup besar dan umumnya diberikan dalam bentuk harta tak bergerak. Sedangkan wakaf untuk harta bergerak belum begitu banyak dikenal oleh masyarakat Indonesia.

Wakaf tunai bagi umat Islam Indonesia memang masih relatif baru, hal ini bisa dilihat dari peraturan yang melandasinya. Majelis Ulama’ Indonesia (MUI) baru memberikan fatwa terkait dengan masalah ini pada pada pertengahan bulan Mei 2002. Sementara landasan hukum Undang-Undang Nomor 41 Tahun 2004 tentang wakaf baru diundangkan pada tanggal 27 Oktober 2004, sedangkan Peraturan Pemerintah Nomor 42 Tahun 2006 tentang pelaksanaanya diundangkan pada tanggal 15 Desember tahun 2006.

\section{G. Strategi Pengembangan Wakaf Tunai Di Desa Sungai Pinang Kecamatan Rambutan Kabupaten Banyuasin}


Secara ekonomi, wakaf tunai sangat potensial untuk dikembangkan di Indonesia, khususnya di desa Sungai Pinang Kecamatan Rambutan Kabupaten Banyuasin. Karena dengan model wakaf tunai ini daya jangkau mobilisasinya akan lebih merata ke sasaran masyarakat yang membutuhkan dibandingkan dengan konsep wakaf tradisionalkonvensional, yaitu dengan bentuk harta fisik yang biasanya dilakukan oleh keluarga yang mampu dan berada.

Salah satu strategi yang dapat dikembangkan dalam memobilisasi wakaf tunai di desa Sungai Pinang Kecamatan Rambutan Kabupaten Banyuasin adalah model dana abadi, yaitu dana yang dihimpun dari berbagai sumber dengan berbagai macam cara yang sah dan halal, kemudian dana yang terhimpun dengan volume besar diinvestasikan dengan tingkat keamanan yang valid melalui lembaga penjamin syariah yang paling tidak mencakup dua aspek pokok, yaitu:

1. Aspek Keamanan; yaitu terjaminnya kemanan nilai pokok dana abadi sehingga tidak terjadi penyusutan (jaminan keutuhan).

2. Aspek Kemanfaatan/Produktifitas; yaitu investasi dari dana abadi tersebut harus bermanfaat dan produktif yang mampu mendatangkan hasil atau pendapatan yang dijamin kehalalannya karena dari pendapatan inilah pembiayaan kegiatan dan program organisasi wakaf dilakukan.

Dalam implementasi operasionalnya, wakaf tunai yang menggunakan konsep dana abadi dapat menerbitkan Sertifikat Wakaf Tunai dengan nominal yang berbeda sesuai dengan kemampuan target dan sasaran yang hendak dituju. Di siniah letak keunggulan dan efektivitas wakaf tunai yang dapat menjangkau berbagai segmen masyarakat yang heterogen. Dengan strategi tersebut paling tidak terdapat empat manfaat yang diperoleh di antaranya: (Haq, $2017: 68$ )

1. Wakaf tunai jumlah dan besarannya dapat bervariasi sesuai dengan kemampuan, sehingga calon wakif yang mempunyai dana terbatas dapat mewakafkan harta benda sesuai dengan tingkat kemampuannya.

2. Melalui wakaf tunai aset-aset wakaf yang berupa tanah-tanah kosong yang tidak produktif dapat dikelola dan dimanfaatkan dengan model pembangunan gedung pendidikan, rumah sakit, serta sarana umum masyarakat yang bermanfaat luas. 
3. Dana wakaf tunai juga dapat disalurkan ke berbagai pihak yang membutuhkan dengan melakukan verifikasi skala kebutuhan secara konkret dan valid, sehingga tepat sasaran sesuai dengan asas kemanfaatan dan kebutuhan yang mempunyai nilai kemaslahatan luas.

4. Dengan dana wakaf tunai yang dikelola secara profesional dapat menumbuhkan kemandirian umat Islam untuk mengatasi problem sosial masyarakat muslim tanpa harus menaruh ketergantungan yang tinggi pada dana bantuan negara atau pihak asing.

\section{H. Simpulan}

1. Masyarakat di Indonesia telah lama mengenal wakaf, namun masih mengenal wakaf berupa benda tidak bergerak seperti tanah dan sebagainya. Masih banyak masyarakat yang belum mengetahui mengenai wakaf tunai, terutama masyarakat tradisional.

2. Wakaf tunai yang dilakukan di desa Sungai Pinang Kecamatan Rambutan Kabupaten Banyuasin merupakan model wakaf tunai yang memiliki daya jangkau mobilisasinya akan lebih merata ke sasaran masyarakat yang membutuhkan dibandingkan dengan konsep wakaf tradisional-konvensional, yaitu dengan bentuk harta fisik yang biasanya dilakukan oleh keluarga yang mampu dan berada.

3. Salah satu strategi yang dapat dikembangkan dalam memobilisasi wakaf tunai di desa Sungai Pinang Kecamatan Rambutan Kabupaten Banyuasin adalah model dana abadi, yaitu dana yang dihimpun dari berbagai sumber dengan berbagai macam cara yang sah dan halal, kemudian dana yang terhimpun dengan volume besar diinvestasikan dengan tingkat keamanan yang valid melalui lembaga penjamin syariah yang paling tidak mencakup dua aspek pokok, yaitu keamanan dan kemanfaatan produk

\section{Saran}

1. Untuk peningkatan pemahaman masyarakat mengenai wakaf tunai, tokoh masyarakat dan pemerintah perlu bekerjasama untuk memberikan sosialisasi dan pemahaman lebih mendalam mengenai wakaf tunai dan potensinya untuk membantu kemandirian ekonomi.

2. Pemerintah juga harus lebih memperhatikan wakaf tunai dari segi pengelolaan, pendayagunaan, dan pelaksanaannya yang telah dilakukan di setiap daerah agar lebih 
berkembang manfaat dan hasilnya sehingga dapat membantu perekonomian masyarakat di Indonesia.

3. Strategi yang digunakan dalam pengelolaan wakaf tunai sebaiknya menerapkan strategi yang tidak akan mengurangi/menghilangkan wujud/pokok dari wakaf itu sendiri.

\section{Daftar Pustaka}

Ali, Maulana Muhammad. 1976. Islamologi (Dinul Islam). Jakarta : PT.Ichtiar Baru Van Hoeve

Alie, Umransyah. 1987. Diktat tentang Hibah, Wasiat dan Wakaf. Banjarmasin: Stihsa

Basyir, Ahmad Azhar. 1987. Hukum Islam tentang Wakaf Ijarah Syirkah Bandung : PT. Alma'arif

Direktorat Pemberdayaan Wakaf. 2007. Pengembangan Wakaf Tunai di Indonesia. Jakarta : Kementerian Agama RI

Haq, Faisal. 2017. Hukum Perwakafan di Indonesia. Jakarta: Rajawali Pers.

Kasdi, Abdurrohman. 2017. Fiqih Wakaf Dari Wakaf Klasik Hingga Wakaf Produktif. Yogyakarta: Idea Press.

Lutfi, Mukhtar. 2013. Manajemen Wakaf : Upaya Progresif dan Inovatif bagi Kesejahteraan Umat. Makassar : Universitas Alauddin

Mardani. 2012. Fiqh Ekonomi Syariah. Jakarta: Kencana.

Muhith, Nur Faizi. 2013. Dahsyatnya Wakaf. Surakarta: Al-Qudwah.

Qahaf, Mundzir. 2005. Manajemen Wakaf Produktif. Jakarta : Khalifa

Suhendi, Hendi. 2010. Fiqh Muamalah. Jakarta: Rajawali Pers.

Usman, Rachmadi. 2013. Hukum Perwakafan di Indonesia, Cet.II. Jakarta : Sinar Grafika 